28 Raine A, Dodge K, Loeber R, Gatzke-Kopp L, Lynam D, Reynolds C, et al. The Reactive-Proactive Aggression Questionnaire: differential correlates of reactive and proactive aggression in adolescent boys. Aggress Behav 2006 32: 159-71.

29 Tuvblad C, Raine A, Zheng M, Baker LA. Genetic and environmental stability differs in reactive and proactive aggression. Aggress Behav 2009; 35: 437-52.

30 Baker LA, Raine A, Liu JH, Jacobson KC. Genetic and environmental influences in reactive and proactive aggression in children. $J$ Child Abnorm Psychol 2008; 36: 1265-78.

31 Frick PJ. Inventory of Callous-Unemotional Traits. University of New Orleans 2004.

32 Wechsler D. The Wechsler Intelligence Scale for Children - Fourth Edition. Pearson Assessment, 2004.
33 Boyce W, Torsheim T, Currie C, Zambon A. The family affluence scale as a measure of national wealth validation of an adolescent self-report measure. Soc Indic Res 2006; 78: 473-87.

34 Muthén LK, Muthén BO. Mplus User's Guide. Muthén \& Muthén, 1998-2011.

35 Brown TA. Confirmatory Factory Analysis for Applied Research. Guilford Press, 2006.

36 Akaike $\mathrm{H}$. A new look at the statistical model identification. IEEE Trans Autom Control 1974; 19: 716-23.

37 Shrout PE, Fleiss JL. Intraclass correlations: uses in assessing reliability. Psychol Bull 1979; 86: 420-8.

38 McGraw KO, Wong SP. Forming inferences about some intraclass correlation coefficients. Psychol Methods 1996; 1: 30-46.

\section{psychiatry and sacred texts}

\title{
Arjuna and Job: depression relieved by submission to gods
}

\author{
John Scott Price, Russell Gardner Jr
}

In the Bhagavad Gita, the hero Arjuna is in a bad situation in that he is required to fight an army composed partly of his mentors, relatives and friends. He has a panic attack and becomes depressed. Krishna advises him to fight, but he will not take Krishna's advice. After 16 chapters of dialogue, Krishna appears to him in his divine form whereupon Arjuna submits to Krishna, and proceeds to fight bravely in the battle.

In the Book of Job, the protagonist is in a bad situation because Satan has killed off his ten children and brought other misfortunes on him. Job becomes depressed and expresses anger at God for treating him unjustly. God then speaks to Job and shows himself, whereupon Job submits to God and his children are restored to him.

These two stories illustrate how submission to a deity may alleviate depression. The story of Job is also of interest because it can be read in two ways. He can be depressed in response to real misfortune, or his misfortunes may be delusional. In favour of the latter, less popular, view is the fact that his comforters do not offer condolence on the deaths of his children and that his children are restored in exactly the same ratio as they were before, suggesting recovery from delusion rather than new births. The speeches of Job's comforters are of interest as examples of how not to comfort the depressed patient.

Arjuna's panic attack is the first description of this pathology in the literature. In Stephen Mitchell's translation:

- "'As I see my own kinsmen, gathered here, eager to fight, my legs weaken, my mouth dries, my body trembles, my hair stands on end, my skin burns, the bow Gandiva drops from my hand, I am beside myself, my mind reels. I see evil omens, Krishna; no good can come from killing my own kinsmen in battle. I have no desire for victory or for the pleasures of kingship" ... Arjuna sank down into the chariot and dropped his arrows and bow, his mind heavy with grief ...

The speeches of the two gods are probably the finest examples of verbal dominance displays in the literature. Even so, they are not effective in inducing submission, which requires the actual sight of the god in both cases. 